\title{
PERFORMANCE OF EMBEDED OF PRECAST BEAM TYPE WET AND DRY JOINT AT MAXIMUM MOMENT
}

\author{
A.Rudi Hermawan ${ }^{1}$, Eka Sasmita Mulya ${ }^{2}$ \\ ${ }^{1,2}$ Politeknik Negeri Jakarta,Teknik Sipil,16425 \\ e-mail: arudihermawan@gmail.com ${ }^{1}$; ekamulya66@yahoo.com ${ }^{2}$
}

\begin{abstract}
Research of perform of embedded precast beam was result many data (a) average tensile strength of joint between plate embedeed with plate joint was 628,55 Mpa (b)average tensile strength of joint between plate with reinforce bar D12,59 was 597,16 Mpa for tensile strength of plate with failure at reinforce bar (c) average tensile strength of reinforce bar D12,59 was 605,23 Mpa and yield strength was 425,87 Mpa (d)average tensile strength of plate 4,58 mm thick was 456,86 Mpa and yield strength was 335,02 Mpa. For welded joint need several control quality so that no hole in that perform of welded couse can decrease tensile strength of joint. Conclusion of this research is embedded for precast concrete type wet and dry can be used for construction of joints of beam.
\end{abstract}

Keywords : Compressive strength; Embedded; Yield strength

\section{INTRODUCTION}

Elements joint of precast concrete which use materials consist of plate and reinforce bar. Research of embedded for precast concrete has been widely done since 1993 and widely used by society of Consultants or Contractors sector.

In 1993 Ugur Ersoy and Tugrul Tankut on research Precast Concrete Members With Welded Plate Connections Under Reversed Cyclic Loading (Ersoy \& Tankut, 1993). This research was used bending embedded element to joint between beam and column for sustain moment and shear occur.

Research of Seismic behavior of a type of welded precast concrete beamcolumn connection by Mario E. Rodríguez, Miguel Torres-Matos concern bending embedded at negative moment in 2013 ( E. Rodríguez \& Torres-Matos, 2013). Andrea Belleri, Paolo Riva in 2012 research concern Seismic performance and retrofit of precast concrete grouted sleeve connections ( Belleri \& Riva, 2012). All research above concern to bending embedded joint system. This research was used unbending embedded joint system which used materials same as with bending embedded. The different is at bend and unbend to reinforce bar.

Goal of this research is making joint with result perform not different to each other system. Result of research wet and dry system with unbending embedded has performed so good to sustain of tension.

\section{METHODS}

Many types of joint for precast concrete in construction and embedded system has been many using in construction sector. Type of Embedded system using materials plate and reinforce bars. To connecting material plate and reinforce bar using electrode to weld between plate and reinforce bar. Figure 1 show element unbending embedded system. 
And can be simple Formulated (318, 2011; (SNI, 2012):

$\mathrm{Ld}=\left(\frac{18 \cdot f y \cdot \alpha \cdot \beta \cdot \lambda \cdot d b}{25 \cdot \sqrt{f c^{\prime}}}\right)>300 \mathrm{~mm}$

where :

fy $\quad=$ Yield Stress ( Mpa )

$\alpha=$ Reinforcement location factor

$\beta=$ Coating factor

$\lambda=$ Ligthweigth aggregate concrete factor

$\mathrm{db} \quad=$ Nominal Diameter

$\mathrm{fc}^{\prime}=$ Compression Concrete $(\mathrm{MPa})$

and another formulated (Rodríguez \& Torres M, 2013; Nadim \& Manaser, 2008)

$\mathrm{Tu}=$ As.fy. $(\mathrm{N})$

$\mathrm{FW}=\mathrm{L} . \mathrm{fsw} . \mathrm{t}$

Where :

$\mathrm{Tu} \quad=$ Tensile Strength Rebar $(\mathrm{N})$

As = Area of Rebar ( $\mathrm{mm} 2)$

$\mathrm{Fw}=$ Shear Strength of Welded $(\mathrm{N})$

$\mathrm{L} \quad=$ Length of Welded ( $\mathrm{mm}$ )

Fsw $=$ Shear Stress of Welded (Mpa)

$\mathrm{t} \quad=$ Thick of Welded $(\mathrm{mm})$

Testing elements was used location at Lembaga Uji Konstruksi (LUK) BPPT Serpong South of Tangerang. This research has 5 samples for tested unbending embedded tensile strength dan 5 samples for tested tensile strength reinforced bars. Reinforced bars used D12,59 and plate which have 4,58 $\mathrm{mm}$ thick with electrode type E.6013 to joint between plate and rebars with $5 \mathrm{~mm}$ thick.

Figure 2 was show prototype of sample test tensile strength of beam and figure 3 was show prototype of reinforced bar and plate tensile strength.

Figure 4 describe of dimension sample test for unbending embedded tensile strength which have measurement of total length of welded $66 \mathrm{~mm}$, length of reinforced bar $400 \mathrm{~mm}$ and dimension of plate $80 / 70 \mathrm{~mm}$ as base of welding.

Figure 5 describe of dimension sample test for unbending embedded tensile strength which have measurement of total length of welded $44 \mathrm{~mm}$, length of plate is $400 \mathrm{~mm}$ and dimension of plate $400 / 80 \mathrm{~mm}$ as base of welding.

Figure 6 show of method of research which was used UTM machine at Puspitek BPPT Serpong and appropriate ASTM standard for test tension of elements.
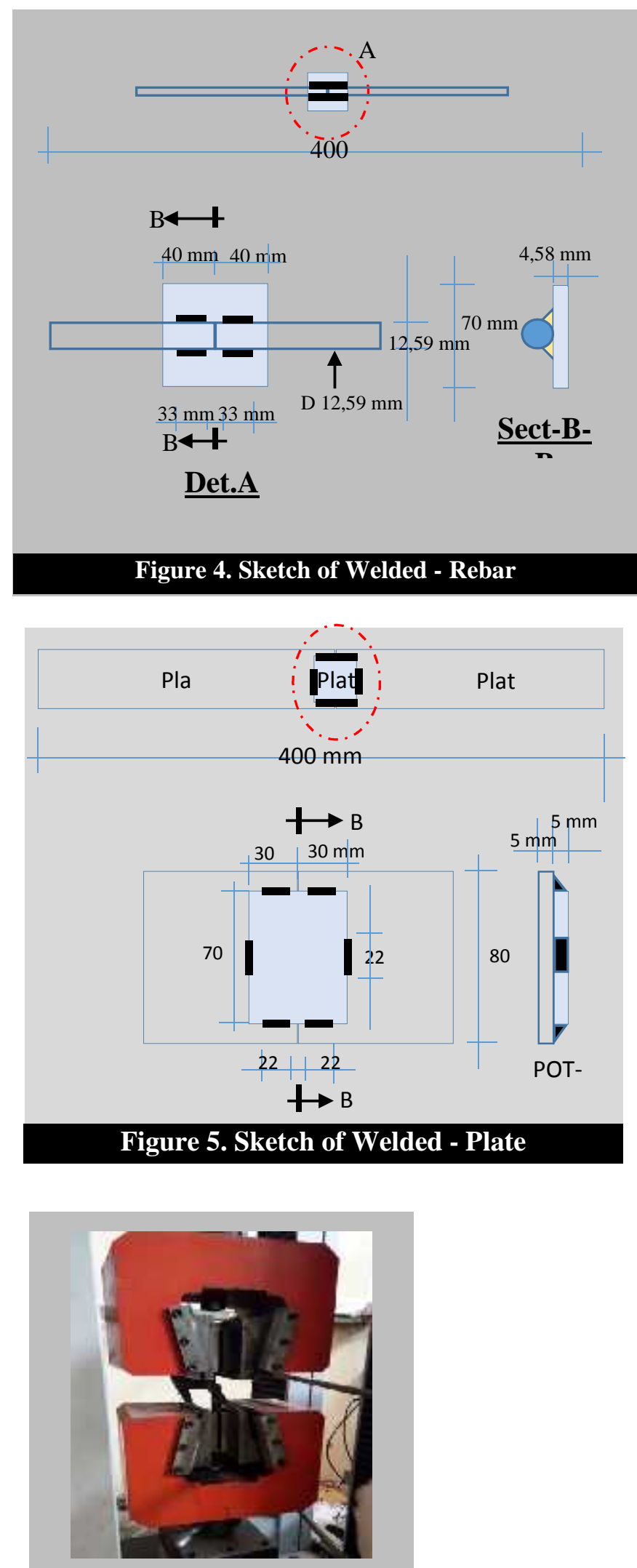

Figure 6. UTM Machine 


\section{RESULTS AND DISCUSSION}

The Research of wet and dry system with unbending embedded for all specimens were capable to resisting tensile load until broken, cause all specimens were its broken at the reinforce bars. Specimen 2A indicated ultimate tensile strength value $608,12 \mathrm{Mpa}$ as ultimate load 75,67 KN, specimen 2B indicated ultimate tensile strength value 609,84 Mpa as ultimate load 75,88 KN, specimen $2 \mathrm{C}$ indicated ultimate tensile strength value 589,38 Mpa as ultimate load 73,21 KN, specimen 2D indicated ultimate tensile strength value 594,29 $\mathrm{Mpa}$ as ultimate load $73,95 \mathrm{KN}$ and specimen $2 \mathrm{E}$ indicated ultimate tensile strength value 585,18 Mpa as ultimate load $72,81 \mathrm{KN}$.

The results of this research was the average value of ultimate tensile strength of unbending embedded 597,16 Mpa as ultimate load $74,31 \mathrm{KN}$ broken at the reinforced bars. Table 1 gives the result of ultimate tensile strength of all specimens unbending embedded system.

Figure 7 show of photo specimens of unbending embedded have tested.The Research of reinforce bars for all specimens were tested until broken. Specimen 4A indicated ultimate tensile strength value $646,47 \mathrm{Mpa}$ as ultimate load $80,44 \mathrm{KN}$, specimen $4 \mathrm{~B}$ indicated ultimate tensile strength value 596,73 Mpa as ultimate load 74,25 KN, specimen $4 \mathrm{C}$ indicated ultimate tensile strength value 592,63 Mpa as ultimate load 73,74 KN, specimen 4D indicated ultimate tensile strength value 593,19 Mpa as ultimate load 73,81 KN and specimen $4 \mathrm{E}$ indicated ultimate tensile strength value $597,13 \mathrm{Mpa}$ as ultimate load 74,30 KN.

The results of this research was the average value of ultimate tensile strength of reinforce bars 605,23 Mpa as ultimate load 75,31 KN.

Table 2 gives the result of ultimate tensile strength of all specimens reinforce bars.

Figure 8 show of photo specimens of reinforce bars until tested.The value of average ultimate tensile strength both of specimens unbending embedded or specimens reinforce bars have resulted almost not different only about $1,01 \mathrm{KN}$ for ultimate load and 8.07 Mpa for ultimate tensile strength and all of specimens broken at the reinforced bar. This result test can be category fulfill of tensile strength and can be used for construction as specially joint of precast concrete.

Figure 11 show chart of load versus stress.

The Research of unbending embedded for all specimens were capable to resisting tensile load until broken, cause all specimens were its broken at the welded. Specimen 1A indicated average ultimate tensile strength value 621,56 $\mathrm{Mpa}$ as ultimate load 92,71 KN, specimen $1 \mathrm{~B}$ indicated average ultimate tensile strength value 640,19 $\mathrm{Mpa}$ as ultimate load 100,16 KN, specimen 1C indicated average ultimate tensile strength value $549,4 \mathrm{Mpa}$ as ultimate load 90,89 KN, specimen 1D indicated average ultimate tensile strength value $561,91 \mathrm{Mpa}$ as ultimate load $88,85 \mathrm{KN}$ and specimen $1 \mathrm{E}$ indicated average ultimate tensile strength value 586,40 Mpa as ultimate load 90,61 KN.

The results of this research was the average value of ultimate tensile strength of unbending embedded 591,89 Mpa as ultimate load 92,64 $\mathrm{KN}$ broken at welded. 
Table 3 gives the result of ultimate tensile strength of all specimens unbending embedded system.

Figure 9 show of photo specimens of unbending embedded have tested.The Research of plates for all specimens were tested until broken. Specimen 3A indicated ultimate tensile strength value 456,38 Mpa as ultimate load 52,34 KN, specimen $3 \mathrm{~B}$ indicated ultimate tensile strength value 445,60 Mpa as ultimate load 52,34 KN, specimen $3 \mathrm{C}$ indicated ultimate tensile strength value 465,14 Mpa as ultimate load 53,11 KN, specimen 3D indicated ultimate tensile strength value 460,79 $\mathrm{Mpa}$ as ultimate load 52,94 $\mathrm{KN}$ and specimen $3 \mathrm{E}$ indicated ultimate tensile strength value 456,61 Mpa as ultimate load 52,53 KN.

The results of this research was the average value of ultimate tensile strength of plates 456,9 Mpa as ultimate load $52,65 \mathrm{KN}$.

Table 4 gives the result of ultimate tensile strength of all specimens plates.

Figure 10 show of photo specimens of plates until tested.The value of average ultimate tensile strength both of specimens unbending embedded or specimens plates have resulted almost not different only about 39,99 $\mathrm{KN}$ for ultimate load and 98.37 Mpa for ultimate tensile strength and all of specimens broken at the plates. This result test can be category fulfill of tensile strength and can be used for construction as specially joint of precast concrete.

Figure 11a and Figure 11b show chart of load versus stress.
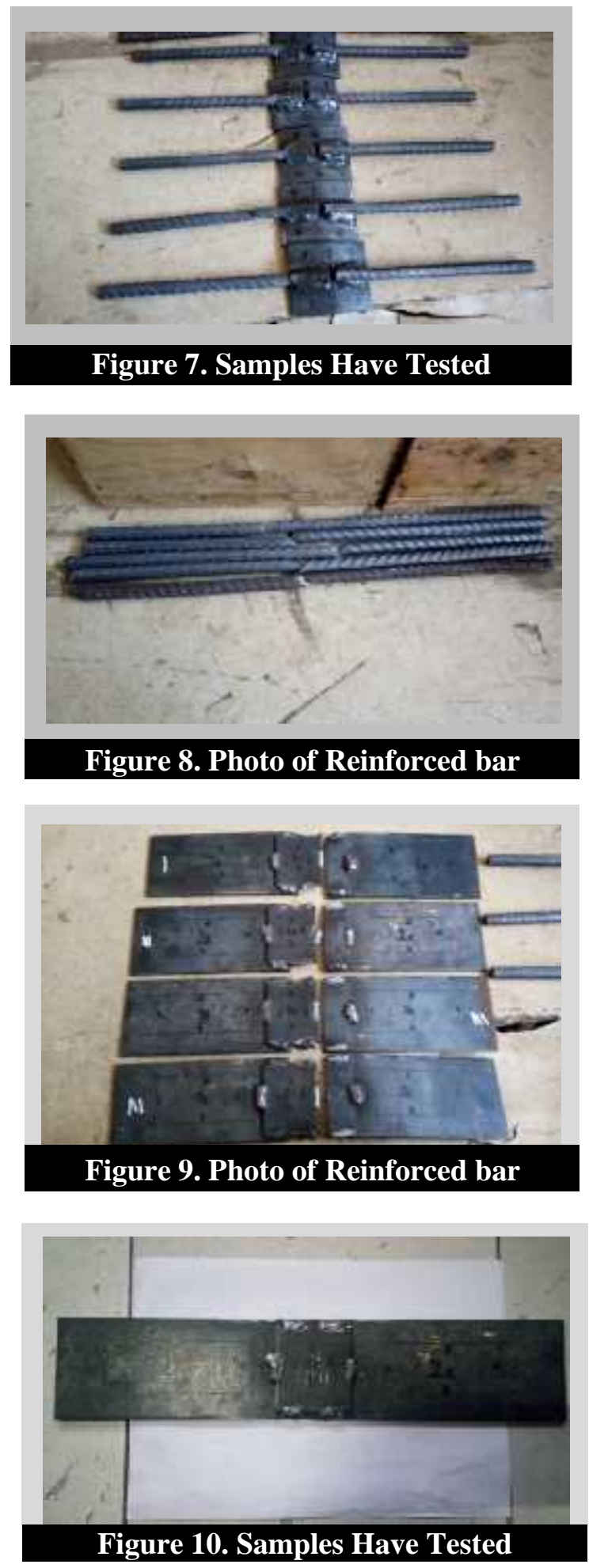
Table 1

Result Test Of Unbending Embedded

\begin{tabular}{ccccccccc}
\hline \multirow{2}{*}{ No } & Sample & Max.Load & t.Plate & L.Rigth & L.Left & fu.Rigth & fu.Left & \multirow{2}{*}{ Result } \\
\cline { 3 - 7 } & & $\mathbf{k N}$ & $\mathbf{m m}$ & $\mathbf{m m}$ & $\mathbf{m m}$ & $\mathbf{M P a}$ & $\mathbf{M P a}$ & \\
\hline $\mathbf{1}$ & 2A & 75.67 & 4.56 & 66.50 & 64.50 & 608.14 & 608.14 & Reinf failed \\
$\mathbf{2}$ & 2B & 75.88 & 4.65 & 67.00 & 65.50 & 609.83 & 609.83 & Reinf failed \\
$\mathbf{3}$ & 2C & 73.21 & 4.54 & 64.00 & 65.50 & 588.37 & 588.37 & Reinf failed \\
$\mathbf{4}$ & 2D & 73.95 & 4.57 & 64.00 & 67.00 & 594.32 & 594.32 & Reinf failed \\
$\mathbf{5}$ & 2E & 72.81 & 4.56 & 65.00 & 64.00 & 585.15 & 585.15 & Reinf failed \\
\hline \multicolumn{2}{r}{ Average } & 74.31 & 4.58 & 65.30 & 65.30 & 597.16 & 597.16 & \\
\hline
\end{tabular}

Table 2.

Result Test Of Reinforce Bar D $12.59 \mathrm{~mm}$

\begin{tabular}{ccccccccc}
\multirow{2}{*}{ No } & Sample & Dia & Area & Fy & Fu & fy & fu & \multirow{2}{*}{ Result } \\
\cline { 3 - 7 } & & $\mathbf{m m}$ & $\mathbf{m m 2}$ & $\mathbf{k N}$ & $\mathbf{k N}$ & $\mathbf{M P a}$ & $\mathbf{M P a}$ & \\
\hline $\mathbf{1}$ & 4A & 12.59 & 124.43 & 58.82 & 80.44 & 472.72 & 646.47 & Reinf failed \\
$\mathbf{2}$ & 4B & 12.59 & 124.43 & 51.83 & 74.25 & 416.54 & 596.73 & Reinf failed \\
$\mathbf{3}$ & 4C & 12.59 & 124.43 & 51.28 & 73.74 & 412.12 & 592.63 & Reinf failed \\
$\mathbf{4}$ & 4D & 12.59 & 124.43 & 50.86 & 73.81 & 408.75 & 593.19 & Reinf failed \\
$\mathbf{5}$ & 4E & 12.59 & 124.43 & 52.16 & 74.30 & 419.20 & 597.13 & Reinf failed \\
\hline \multicolumn{2}{r}{ Average } & & & 52.99 & 75.31 & 425.87 & 605.23 & \\
\hline
\end{tabular}

\begin{tabular}{|c|c|c|c|c|c|c|c|c|}
\hline & & & Rest & $\begin{array}{r}\mathrm{Ta} \\
\text { Test of } \mathrm{V}\end{array}$ & $\begin{array}{l}3 \\
\text { lded Pla }\end{array}$ & Plate & & \\
\hline No & Sample & MaxLoad & $\begin{array}{c}\text { t } \\
\text { plate }\end{array}$ & L.Rigth & L.Left & fu.Rigth & fu.Left & Exp. \\
\hline & & kN & $\mathbf{m m}$ & $\mathbf{m m}$ & $\mathbf{m m}$ & Мра & Мpa & \\
\hline 1 & $1 \mathrm{~A}$ & 92.71 & 4.56 & 55.50 & 64.50 & 668.18 & 574.95 & $\begin{array}{l}\text { Welded } \\
\text { failed }\end{array}$ \\
\hline 2 & 1B & 100.16 & 4.65 & 59.50 & 66.00 & 673.34 & 607.03 & $\begin{array}{c}\text { Welded } \\
\text { failed }\end{array}$ \\
\hline 3 & $1 \mathrm{C}$ & 90.89 & 4.54 & 64.00 & 68.50 & 568.06 & 530.74 & $\begin{array}{c}\text { Welded } \\
\text { failed }\end{array}$ \\
\hline 4 & 1D & 88.85 & 4.57 & 59.50 & 67.50 & 597.31 & 526.52 & $\begin{array}{c}\text { Welded } \\
\text { failed }\end{array}$ \\
\hline 5 & $1 \mathrm{E}$ & 90.61 & 4.56 & 57.00 & 67.50 & 635.86 & 536.95 & $\begin{array}{c}\text { Welded } \\
\text { failed }\end{array}$ \\
\hline & erage & 92.64 & 4.58 & 59.10 & 66.80 & 628.55 & 555.24 & \\
\hline
\end{tabular}



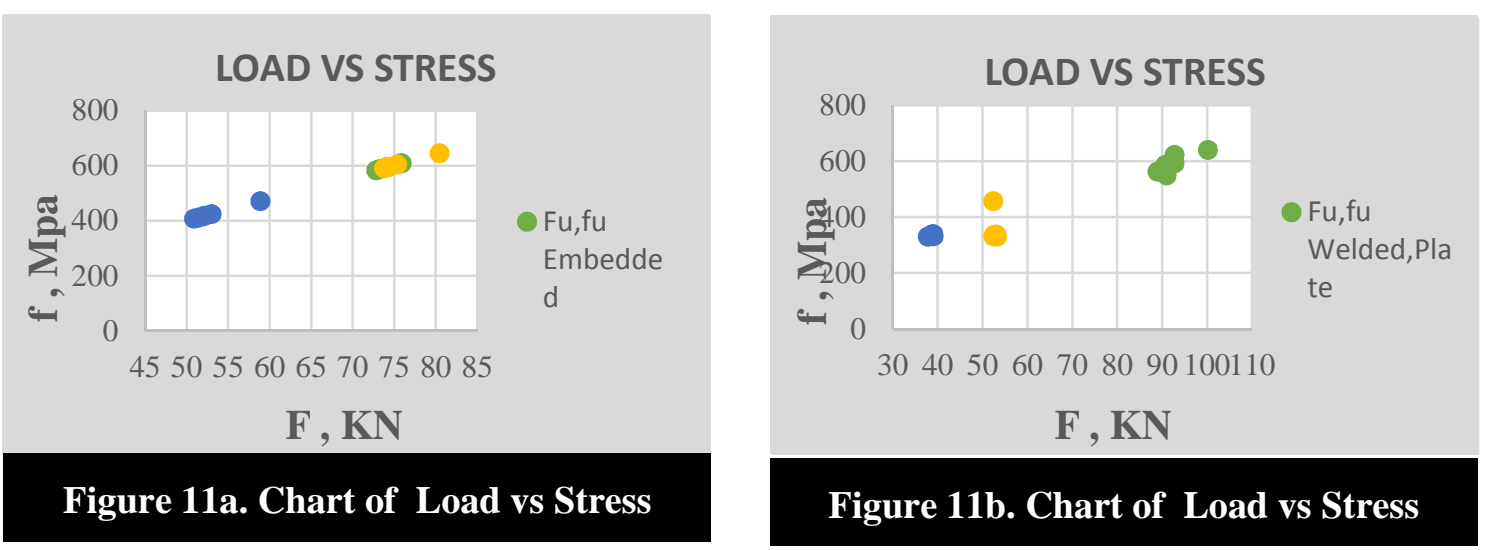

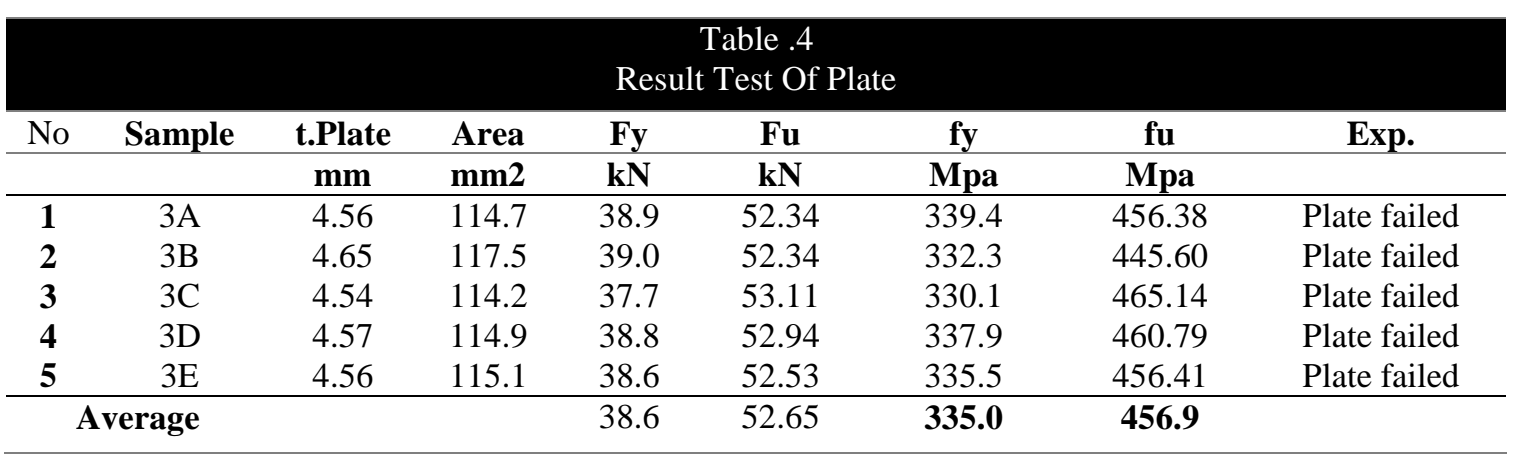

\section{CONCLUSION}

Result of test element joint of precast beam indicates that embedded with type wet and dry joint can be used for connection between element of precast beam joint.

\section{REFERENCES}

Belleri, A., \& Riva, P. (2012). Seismic performance and retrofit of precast concrete grouted sleeve connections. 57(1), 97-109.

E. Rodríguez, M., \& Torres-Matos, M. (2013). Seismic behavior of a type of welded precast concrete beamcolumn connection. 58(3), 81-94.

318, A. C. (2011). Building Code Requirments for Structure and Commentary. Detroit: American Concrete Institute.

Ersoy, U., \& Tankut, T. (1993, JulyAugust). Precast Concrete Members with Welded Plate
Connections Under Reversed Cyclic Loading. PCI Jurnal Paper, 38(4), 94-100.

Nadim, M., \& Manaser, A. (2008).

Structural Concrete : Theory and Design. USA: John Wiley and Sons.

Rodríguez, \& Torres M, S. (2013).

Seismic Behavior of type of welded precast concrete beamcolum connection. PCI Journal Paper, 58(3), 81-94.

SNI. (2012). 03-2847-2012, SNI, Standar Nasional Indonesia ,Tata Cara Perhitungan Struktur Beton Untuk Bangunan Gedung. Bandung. 